\title{
PEMBELAJARAN MISSOURI MATHEMATICS PROJECT DAN \\ PENEMUAN TERBIMBING TERHADAP HASIL BELAJAR MATEMATIKA DITINJAU DARI KEMAMPUAN AWAL DI SMK
}

\author{
Istiqomah \\ SMK Negeri 3 Klaten \\ istiqomahsubagya1971@yahoo.co.uk
}

\begin{abstract}
The aims of this study are to test: 1) the differences of the influences between MMP learning strategy and Guided Discovery learning strategy towards mathematics learning outcomes, 2) the differences of the influences between students' initial ability level towards mathematics learning outcomes, and 3) the interaction between MMP learning strategy and students' initial ability level towards mathematics learning outcomes. The Quasi-experimental research design used the population of all students from class XI of SMKN 3 Klaten. This research uses cluster sampling. Data were collected by documentation and tests. Technical analysis used anava, different two way cells, and then followed by Scheffe method. The results of this study showed: 1) the students' learning outcomes by using MMP learning strategy are better than by guided discovery learning strategy, 2) the students' learning outcomes of high initial ability level students is better than middle and low initial ability level students, and the students' learning outcomes of middle initial ability level students is better than low initial ability level students, and 3) MMP learning strategy is more effective than guided discovery learning strategy towards middle initial ability level students. MMP learning strategy, the learning outcomes of high initial ability level students is better than middle and low initial ability level students, the learning outcomes of middle initial ability level students is better than low initial ability level students. Meanwhile, guided discovery learning strategy, the learning outcomes of high initial ability level students is better than middle and low initial ability level students. As for, in guided discovery learning strategy, the learning outcomes between middle and low initial ability level students gets the same learning outcomes.
\end{abstract}

Keywords: learning outcomes; Missouri Mathematics Project; guided discovery

\begin{abstract}
Abstrak. Penelitian ini bertujuan untuk menguji 1) perbedaan pengaruh strategi pembelajaran Missouri Mathematics Project dan penemuan terbimbing terhadap hasil belajar matematika, 2) perbedaan pengaruh tingkat kemampuan awal siswa terhadap hasil belajar matematika, dan 3) interaksi strategi pembelajaran dan tingkat kemampuan awal siswa terhadap hasil belajar. Desain penelitian Quasi exsperimental. Populasinya semua siswa kelas XI SMK Negeri 3 Klaten. Pengambilan sampel dengan cluster sampling. Metode pengumpulan data dengan dokumentasi dan tes. Teknik analisis dengan Anava dua jalan sel tidak sama, dilanjutkan metode Scheffe. Hasil penelitian dengan taraf signifikansi 0,05 menunjukkan 1) Hasil belajar siswa dengan strategi Missouri Mathematics Project lebih baik daripada strategi penemuan terbimbing, 2) Hasil belajar siswa berkemampuan awal tinggi lebih baik daripada siswa berkemampuan awal sedang dan rendah, hasil belajar siswa berkemampuan awal sedang lebih baik daripada siswa berkemampuan awal rendah.3) Strategi MMP lebih efektif dibanding penemuan terbimbing pada siswa
\end{abstract}


berkemampuan awal sedang. Pada strategi MMP, siswa berkemampuan awal tinggi hasil belajarnya lebih baik daripada siswa berkemampuan awal sedang dan rendah, dan siswa berkemampuan awal sedang hasil belajarnya lebih baik daripada siswa berkemampuan awal rendah. Sedang pada strategi penemuan terbimbing siswa berkemampuan awal tinggi hasil belajarnya lebih baik daripada siswa berkemampuan awal sedang dan rendah. Adapun siswa berkemampuan awal sedang dan rendah mendapatkan hasil belajar yang sama.

Kata kunci: Hasil Belajar; Missouri Mathematics Project; Penemuan Terbimbing

\section{Pendahuluan}

Matematika merupakan ilmu yang mendasari perkembangan teknologi modern, mempunyai peran penting di berbagai disiplin ilmu dan dalam mengembangkan daya pikir manusia. Hal ini sesuai pendapat Aminu bahwa matematika adalah dasar dari semua ilmu dan aplikasi teknologi yang melintasi semua bidang pengetahuan manusia (Akanmu, 2013: 82). Untuk mempersiapkan peserta didik menghadapi era teknologi, para pendidik mengubah isi kurikulum dan cara mengajarkannya. Hal ini sesuai pendapat Robertson yaitu ketika memikirkan cara terbaik untuk mempersiapkan siswa menghadapi semua tantangan dunia, para pendidik mengubah isi kurikulum dari fokus aritmatika dan keterampilan berhitung menjadi kurikulum yang mampu mengembangkan kemampuan siswa untuk berpikir, bernalar, dan berkomunikasi secara matematis. Tujuannya adalah membantu siswa membangun pemahaman konseptual matematika mereka, bukan sekedar mengingat fakta dan aturan-aturannya (Sharan, 2012: 408).

Kenyataan di lapangan pembelajaran matematika belum sesuai harapan dan hasil belajar matematika di Indonesia masih tergolong rendah. Hal ini dapat dilihat dari peringkat yang didasarkan pada matematika dan sains untuk usia 15 tahun, pada tahun 2015 Indonesia berada di peringkat 69 dari 76 negara (berdasarkan sumber www.bbc. com), (Coughlan, 2015). Rata-rata hasil Ujian Nasional (UN) tahun 2015 tingkat SMA/SMK/MANpada pelajaran matematika di Indonesia 61,3 (berdasarkan sumber www. antaranews.com), (Indriani, 2015). Angka tersebut masih belum sesuai harapan.

Berdasarkan pengamatan awal, pembelajaran di SMK Negeri 3 Klaten cenderung text book oriented. Pembelajaran tersebut kurang terkait dengan kehidupan sehari-hari siswa, sehingga konsep-konsep akademik sulit dipahami. Akibatnya hasil belajar matematika banyak yang masih dibawah kriteria ketuntasan minimal (KKM). KKM matematika kelas XI di SMK Negeri 3 Klaten 70,00 , sementara rata-rata nilai ujian semester gasal kelas XI 68,00. Rendahnya hasil belajar matematika tersebut dipengaruhi oleh beberapa faktor yaitu faktor siswa, guru dan fasilitas sekolah.

Kesenjangan lain di lapangan adalah bahwa guru dalam mengajar cenderung kurang memperhatikan kemampuan awal siswa. Guru kurang melakukan pengajaran bermakna, strategi pembelajaran yang digunakan kurang bervariasi, sehingga membuat peserta didik bosan dalam menerima pelajaran. Maka tugas professional seorang guru yaitu menjadikan pelajaran menjadi lebih menarik, yang dirasakan sulit menjadi mudah, yang tadinya tidak berarti menjadi bermakna, sehingga kualitas pembelajaran dapat ditingkatkan.

Di dalam pembelajaran matematika, guru harus mampu membuat siswa menjadi aktif selama proses pembelajaran, sehingga ada perubahan yaitu pembelajaran yang berpusat pada guru diubah menjadi pembelajaran yang berpusat pada siswa. Dibentuknya kelompok belajar juga akan membuat 
suasana pembelajaran lebih menyenangkan dan mempersilahkan siswa bersama-sama memecahkan masalah yang dihadapi. Dalam belajar kelompok dapat memberikan kesempatan siswa untuk mengembangkan ide-ide matematika dan memecahkan masalah yang dihadapi (Francisco, 2012: 1).

Namun kenyataan menunjukkan bahwa sampai saat ini masih banyak pembelajaran yang berpusat pada guru sehingga siswa belum terarahkan untuk menemukan sendiri konsep-konsep matematika yang sedang dipelajari.Pendekatan tradisional tersebut belum mampu mengembangkan kemampuan kognitif (penalaran), afektif (sikap), dan psikomotorik (keterampilan) siswa. Dengan demikian siswa hanya cenderung menghafalkan konsep-konsep matematika yang dipelajarinya tanpa memahami dengan benar.Akibatnya pemahaman terhadap pemecahan permasalahan dalam matematika menjadi sangat kurang.Selain itu guru sebagai pemberi informasi cenderung mendominasi kegiatan pembelajaran di kelas sehingga tidak terjadi hubungan timbal balik antar guru dan siswa yang berimplikasi terhadap kualitas hasil belajar matematika.

Untuk mengatasi permasalahan tersebut, sudah saatnya diadakan pembaharuan, inovasi atau gerakan perubahan pembelajaran kearah pencapaian tujuan pendidikan. Guru diharapkan menerapkan strategi pembelajaran yang efektif agar siswa dapat memahami materi yang disampaikan sesuai dengan tujuan yang diharapkan. Situasi pembelajaranyang interaktif dan komunikatif yang melibatkan partisipasi aktif siswa dan dapat melatih siswa belajar menemukan konsep sendiri.

Banyak strategi pembelajaran yang dikembangkan oleh para ahli, namun saat diterapkan seringkali hasilnya kurang efektif. Hasil penelitian ini diharapkan diperoleh strategi pembelajaran matematika SMK yang dapat dijadikan contoh oleh guru. Sehingga mutu proses pembelajaran lebih baik dan diyakini akan meningkatkan hasil belajar siswa. Keyakinan ini didukung oleh penelitian
terdahulu.Penelitian Marliani (2015: 14) menemukan bahwa penggunaan strategi pembelajaran Missouri Mathematics Project (MMP) dapat meningkatkan kemampuan berpikir kreatif siswa. Penelitian Jannah, dkk. (2013: 61) menunjukkan bahwa penggunaan strategi pembelajaran Missouri Mathematics Project mampu meningkatkan pemahaman dan sikap positif siswa terhadap pelajaran matematika.

Bertolak dari pemikiran tersebut, peneliti ingin mengadakan suatu eksperimen tentang pembelajaran matematika dengan Missouri Mathematics Project (MMP) dan Penemuan terbimbing (Guided Discovery) dengan mengajukan tiga hipotesis: 1) Ada perbedaan pengaruh yang signifikan antara strategi pembelajaran terhadap hasil belajar matematika siswa; 2) Ada perbedaan pengaruh yang signifikan antara kemampuan awal terhadap hasil belajar matematika siswa; 3) Terdapat interaksi antara strategi pembelajaran dan kemampuan awal siswa terhadap hasil belajar matematika.

\section{Metode}

Jenis penelitian yang dilakukan ini merupakan penelitian kuantitatif dengan desain eksperimental semu (Quasi exsperimental), karena peneliti tidak mungkin mengontrol semua variabel yang relevan. Eksperimental semu banyak digunakan oleh peneliti karena kenyataan praktis bahwa mereka mendapatkan kesukaran untuk mengumpulkan kelompok kontrol yang akan disertakan dalam penelitian (Sutama, 2015: 57).

Teknik pengumpulan data pada penelitian ini menggunakan dokumentasi untuk memperoleh data ulangan harian dan data kemampuan awal siswa yakni nilai tes akhir semester gasal tahun 2015/2016 serta tes untuk mengumpulkan data mengenai hasil belajar matematika siswa kelas eksperimen.

Data yang diperoleh dalam penelitian ini pada awalnya dilakukan uji keseimbangan atau uji beda rerata dengan analisis uji-t. Kemudian dilakukan prasyarat analisis yaitu 
uji normalitas dengan metode Lilliefors. digunakan untuk mengetahui apakah data yang diperoleh dari instrumen penelitian ini dari populasi berdistribusi normal atau tidak dan uji homogenitas dengan metode Bartlett digunakan untuk mengetahui apakah populasi penelitian mempunyai variansi yang sama atau tidak.

Untuk pengujian hipotesis digunakan analisis variansi dua jalan sel tidak sama. Kemudian dilakukan uji komparasi ganda sebagai tindak lanjut dari analisis variansi. Uji ini dilakukan apabila hasil dari analisis variansi menunjukkan $\mathrm{H}_{0}$ ditolak maka perlu dilakukan uji lanjut pasca anava yaitu menggunakan Metode Scheffe'.

\section{Hasil dan Pembahasan}

Hasil belajar matematika diukur dengan instrumen tes. Bentuk tes hasil belajar matematika pilihan ganda berjumlah 30 dengan distraktor masing-masing 5. Sebelum instrumen digunakan diuji validitas item dengan menggunakan korelasi biserial titik $\left(\mathrm{r}_{\mathrm{pbis}}\right)$. Uji reliabilitas instrumen tes pada penelitian ini dihitung dengan rumus Kuder Richardson dengan KR-20. Didapat $r_{11}=$ 0,915 dengan demikian $r_{11} \geq 0,70$, sehingga soal tes mempunyai reliabilitas tinggi, atau dapat dikatakan tes reliabel. Uji keseimbangan dengan uji $\mathrm{t}$, diperoleh hasil $=1,9983$ daerah kritis DK $=\{\mathrm{t} \mid \mathrm{t}<-1,9983$ atau $\mathrm{t}>1,9983$ \} dan $\quad t_{\text {obs }}=1,2028 \notin D K$ sehingga $\mathrm{H}_{0}$ diterima, berarti kedua kelompok eksperimen berasal dari populasi yang berkemampuan awal sama.

Data kemampuan awal siswa pada materi transformasi geometri pada siswa kelompok eksperimen MMP yaitu 33 siswa kelas XI Tata Busana 1 SMK Negeri 3 Klaten, diperoleh nilai tertinggi 84,00 ; nilai terendah 56,00 ; rerata 69,7576; variansi 59,6269 dan standar deviasi 7,7218. Data kemampuan awal siswa pada materi transformasi geometri pada siswa kelompok eksperimen GD yaitu 30 siswa kelas XI Tata Kecantikan Kulit SMK Negeri 3 Klaten, diperoleh nilai tertinggi 84,00 ; nilai terendah 56,00 ; rerata 67,4333 ; variansi 57,6333 dan standar deviasi 7,5917. Berdasarkan data yang diperoleh pada kelas eksperimen MMP dan GD akan dikatagorikan dalam tiga katagori yaitu tinggi, sedang dan rendah. Dari hasil perhitungan gabungan antara kelompok eksperimen MMP dan GD diperoleh rerata 68,651 dan standar deviasi 7,688 .

Data hasil belajar matematika pada materi transformasi geometri pada siswa kelompok eksperimen MMP yaitu 33 siswa kelas XI Tata Busana 1 SMK Negeri 3 Klaten, diperoleh nilai tertinggi 86,67 ; nilai terendah 56,67 ; rerata 73,6361 ; variansi 54,4916 dan standar deviasi 7,5161. Data hasil belajar matematika materi transformasi geometri pada siswa kelompok eksperimen GD yaitu 30 siswa kelas XI Tata Kecantikan Kulit SMK Negeri 3 Klaten, diperoleh nilai tertinggi 80,00 ; nilai terendah 56,67 ; rerata 68,223 ; variansi 42,7659 dan standar deviasi 6,7650 .

Uji normalitas dengan menggunakan uji Lilliefors memperoleh hasil bahwa sampel berasal dari populasi yang berdistribusi normal. Rangkuman dari uji normalitas tes hasil belajar seperti pada tabel berikut:

Tabel 1 Rangkuman Uji Normalitas Tes Hasil Belajar

\begin{tabular}{lccc}
\hline Uji Normalitas & $\mathbf{L}_{\text {obs }}$ & $\mathbf{L}_{\text {tabel }}$ & Kesimpulan \\
\hline Kelas MMP & 0,092 & 0,154 & $\mathrm{~L}_{\text {obs }} \notin \mathrm{DK}$ \\
Kelas Penemuan Terbimbing & 0,131 & 0,162 & $\mathrm{~L}_{\text {obs }} \notin \mathrm{DK}$ \\
Kelompok kemampuan awal tinggi & 0,150 & 0,234 & $\mathrm{~L}_{\text {obs }} \notin \mathrm{DK}$ \\
Kelompok kemampuan awal sedang & 0,134 & 0,150 & $\mathrm{~L}_{\text {obs }} \notin \mathrm{DK}$ \\
Kelompok kemampuan awal rendah & 0,186 & 0,220 & $\mathrm{~L}_{\text {obs }} \notin \mathrm{DK}$ \\
\hline
\end{tabular}


uji homogenitas dengan menggunakan Sedangkan rangkuman dari homogenitas uji Bartlett memperoleh hasil bahwa sampel hasil belajar matematika adalah sebagai berasal dari populasi yang homogeny. berikut:

Tabel 2 Rangkuman Uji Homogenitas Hasil Belajar

\begin{tabular}{lcccc}
\hline \multicolumn{1}{c}{ Uji Homogenitas } & $X_{\text {obs }}^{2}$ & $X_{\text {tabel }}^{2}$ & Keputusan & Kesimpulan \\
\hline Strategi Pembelajaran & 0,1286 & 3,841 & $\mathrm{H}_{0}$ diterima & Homogen \\
Tingkat KA & 1,7684 & 5,991 & $\mathrm{H}_{0}$ diterima & Homogen \\
\hline
\end{tabular}

Hasil analisis variansi dua jalan dengan sel tak sama, dengan taraf signifikansi $\alpha=0.05$, dapat dilihat pada tabel berikut:

Tabel 3 Rangkuman Analisis Variansi Dua Jalan

\begin{tabular}{lcccccc}
\hline Sumber & $\mathrm{JK}$ & $\mathrm{dk}$ & $\mathrm{RK}$ & $\mathrm{F}_{\text {obs }}$ & $\mathrm{F}$ & Kesimpulan \\
\hline Strategi (A) & 111,017 & 1 & 111,017 & 4,695 & 4,01 & $\mathrm{~F}_{\mathrm{a}} \in \mathrm{DK}$ \\
KA (B) & 2097,020 & 2 & 1048,510 & 44,346 & 3,16 & $\mathrm{~F}_{\mathrm{a}} \in \mathrm{DK}$ \\
Interaksi (AB) & 172,137 & 2 & 86,068 & 3,640 & 3,16 & $\mathrm{~F}_{\mathrm{a}} \in \mathrm{DK}$ \\
Galat (G) & 1347,707 & 57 & 23,644 & & & \\
Total (T) & 3727,880 & 62 & & & & \\
\hline
\end{tabular}

Tabel rangkuman analisis variansi dua jalan pada strategi pembelajaran tersebut, menyatakan bahwa $\mathrm{F}_{\mathrm{a}}=4,695$ dan $\mathrm{F}_{\text {tabel }}$ $=4,01$ sedangkan daerah kritik untuk $\mathrm{F}_{\mathrm{a}}$ adalah $\mathrm{DK}=\{\mathrm{F} \mid \mathrm{F}>4,01\}, \mathrm{F}_{\mathrm{a}} \in \mathrm{DK}$. Kesimpulannya $\mathrm{H}_{0 \mathrm{~A}}$ ditolak, ini berarti pada tingkat signifikan $\alpha=0,05$ ada perbedaan pengaruh yang signifikan antara strategi pembelajaran terhadap hasil belajar matematika siswa pada materi transformasi geometri.

Tabel rangkuman analisis variansi dua jalan pada kemampuan awal tersebut, menyatakan bahwa $\mathrm{F}_{\mathrm{b}}=44,346$ dan $\mathrm{F}_{\text {tabel }}$ $=3,16$ sedangkan daerah kritik untuk $\mathrm{F}_{\mathrm{b}}$ adalah $\mathrm{DK}=\{\mathrm{F} \mid \mathrm{F}>3,16\}, \mathrm{F}_{\mathrm{b}} \in \mathrm{DK}$. Kesimpulannya $\mathrm{H}_{0 \mathrm{~B}}$ ditolak, ini berarti pada tingkat signifikan $\alpha=0,05$ ada perbedaan pengaruh yang signifikan antara tingkat kemampuan terhadap hasil belajar matematika.

Tabel rangkuman analisis variansi dua jalan pada strategi pembelajaran dan kemampuan awaltersebut, menyatakan bahwaF $\mathrm{F}_{\mathrm{ab}}=3,640$ dan $\mathrm{F}_{\text {tabel }}=3,16$ sedangkan daerah kritik untuk $\mathrm{F}_{\mathrm{ab}}$ adalah $\mathrm{DK}=\{\mathrm{F} \mid$ $\mathrm{F}>3,16\}, \mathrm{F}_{\mathrm{ab}} \in \mathrm{DK}$. Kesimpulannya $\mathrm{H}_{0 \triangle \mathrm{B}}$ ditolak, ini berarti pada tingkat signifikan $\alpha=0,05$ terdapat interaksi antara strategi pembelajaran dan kemampuan awal siswa terhadap hasil belajar matematika.

Berdasarkan hasil analisis variansi dua jalan pada sel tak sama diperoleh bahwa $\mathrm{H}_{0 \mathrm{~A}}$ ditolak. Pada rerata antar baris tidak perlu dilakukan uji komparasi karena hanya terdiri dari dua katagori sehingga cukup dengan melihat rerata marginalnya saja. 
Tabel 4 Rerata Masing-Masing Sel

\begin{tabular}{|c|c|c|c|c|c|}
\hline \multirow{2}{*}{$\begin{array}{c}\text { KA } \\
\text { Strategi }\end{array}$} & \multicolumn{3}{|c|}{ Kemampuan Awal } & \multirow{2}{*}{\multicolumn{2}{|c|}{$\begin{array}{c}\text { Rerata } \\
\text { Marginal N }\end{array}$}} \\
\hline & Tinggi & Sedang & Rendah & & \\
\hline MMP & 81,67 & 73,86 & 62,22 & 73,6361 & 33 \\
\hline Penemuan terbimbing & 76,67 & 67,71 & 64,45 & 68,2227 & 30 \\
\hline Rerata Marginal & 79,742 & 71,143 & 63,557 & & \\
\hline $\mathrm{N}$ & 13 & 35 & 15 & & 63 \\
\hline
\end{tabular}

Berdasarkan hasil analisis variansi dua jalan pada sel tak sama diperoleh bahwa $\mathrm{H}_{0 \mathrm{~B}}$ ditolak, sehingga perlu dilakukan uji lanjut

dengan menggunakan uji komparasi ganda pada rerata antar kolom.

Tabel 5 Rangkuman Analisis Komparasi Ganda Antar Kolom

\begin{tabular}{ccccc}
\hline Hipotesis & Statistik Uji F & $\mathbf{F}_{\text {kritik }}$ & Keputusan Uji & Kesimpulan \\
\hline$\mu_{1}=\mu_{2}$ & 29,648 & 6,32 & $\mathrm{H}_{0}$ ditolak & $\mathrm{F}_{1-2} \mathbf{\epsilon} \mathrm{DK}$ \\
$\mu_{2}=\mu_{3}$ & 26,727 & 6,32 & $\mathrm{H}_{0}$ ditolak & $\mathrm{F}_{2-3} \mathbf{\epsilon} \mathrm{DK}$ \\
$\mu_{1}=\mu_{3}$ & 77,164 & 6,32 & $\mathrm{H}_{0}$ ditolak & $\mathrm{F}_{1-3} \mathbf{\epsilon} \mathrm{DK}$ \\
\hline
\end{tabular}

$\mathrm{F}_{1-2}: \mathrm{H}_{0}$ ditolak, maka ada perbedaan pengaruh yang signifikan antara siswa yang mempunyai kemampuan awal tinggi dan siswa yang mempunyai kemampuan awal sedang terahadap hasil belajar matematika. $\mathrm{F}_{2-3}: \mathrm{H}_{0}$ ditolak, maka ada perbedaan pengaruh yang signifikan antara siswa yang mempunyai kemampuan awal sedang dan siswa yang mempunyai kemampuan awal rendah terhadap hasil belajar matematika. pengaruh yang signifikan antarasiswa yang mempunyai kemampuan awal tinggi dan siswa yang mempunyai kemampuan awal rendah terhadap hasil belajar matematika.

Berdasarkan hasil analisis variansi dua jalan pada sel tak sama diperoleh bahwa $\mathrm{H}_{0 \mathrm{AB}}$ ditolak, sehingga perlu dilakukan uji lanjut dengan menggunakan uji komparasi ganda antar sel pada pada kolom yang sama dan antar sel pada baris yang sama. $\mathrm{F}_{1-3}: \mathrm{H}_{0}$ ditolak, maka ada perbedaan

Tabel 6 Rangkuman Analisis Komparasi Ganda Antar Sel pada kolom yang sama

\begin{tabular}{ccccl}
\hline Hipotesis & Statistik Uji F & $\mathbf{F}_{\text {kritik }}$ & Keputusan Uji & Kesimpulan \\
\hline$\mu_{11}=\mu_{21}$ & 3,252 & 11,90 & $\mathrm{H}_{0}$ diterima & $\mathrm{F}_{11-21} \notin \mathrm{DK}$ \\
$\mu_{12}=\mu_{22}$ & 13,898 & 11,90 & $\mathrm{H}_{0}$ ditolak & $\mathrm{F}_{12-22} \mathrm{CK}$ \\
$\mu_{13}=\mu_{23}$ & 0,752 & 11,90 & $\mathrm{H}_{0}$ diterima & $\mathrm{F}_{13-23} \notin \mathrm{DK}$ \\
\hline
\end{tabular}

Tabel tersebut, menyatakan bahwa daerah kritik uji komparasi ganda antar sel pada kolom yang sama $\mathrm{DK}=\{\mathrm{F} \mid \mathrm{F}>11,90$, dan hasil yang ditunjukkan $\mathrm{F}_{11-21}: \mathrm{H}_{0}$ diterima, maka tidak ada perbedaan hasil belajar matematika antara strategi pembelajaran MMP dan penemuan terbimbing pada siswa yang mempunyai kemampuan awal tinggi. $\mathrm{F}_{12-22}: \mathrm{H}_{0}$ ditolak, maka ada perbedaan hasil belajar matematika antara strategi pembelajaran MMP dan penemuan terbimbing pada siswa yang mempunyai kemampuan awal sedang. $\mathrm{F}_{13-33}: \mathrm{H}_{0}$ diterima, maka tidak ada perbedaan hasil belajar matematika antara strategi pembelajaran MMP dan penemuan terbimbing pada siswa yang mempunyai kemampuan awal rendah. 
Tabel 7 Rangkuman Analisis Komparasi Ganda Antar Sel pada baris yang sama

\begin{tabular}{ccccc}
\hline Hipotesis & Statistik Uji F & $\mathbf{F}_{\text {kritik }}$ & Keputusan Uji & Kesimpulan \\
\hline$\mu_{11}=\mu_{12}$ & 14,507 & 11,90 & $\mathrm{H}_{0}$ ditolak & $\mathrm{F}_{11-12} \mathbf{\epsilon} \mathrm{DK}$ \\
$\mu_{11}=\mu_{13}$ & 54,810 & 11,90 & $\mathrm{H}_{0}$ ditolak & $\mathrm{F}_{11-13} \mathbf{\epsilon} \mathrm{DK}$ \\
$\mu_{12}=\mu_{13}$ & 26,113 & 11,90 & $\mathrm{H}_{0}$ ditolak & $\mathrm{F}_{12-13} \mathbf{c ~ D K}$ \\
$\mu_{21}=\mu_{22}$ & 12,927 & 11,90 & $\mathrm{H}_{0}$ ditolak & $\mathrm{F}_{21-22} \mathbf{\epsilon} \mathrm{DK}$ \\
$\mu_{21}=\mu_{23}$ & 25,001 & 11,90 & $\mathrm{H}_{0}$ ditolak & $\mathrm{F}_{21-23} \mathbf{c ~ D K}$ \\
$\mu_{22}=\mu_{23}$ & 2,594 & 11,90 & $\mathrm{H}_{0}$ diterima & $\mathrm{F}_{22-23} \notin \mathrm{DK}$ \\
\hline
\end{tabular}

Tabel tersebut, menyatakan bahwa daerah kritik uji komparasi ganda antar sel pada kolom yang sama $\mathrm{DK}=\{\mathrm{F} \mid \mathrm{F}>$ 11,90, dan hasil yang ditunjukkan $\mathrm{F}_{11-12}$ : $\mathrm{H}_{0}$ ditolak, maka ada interaksi antarasiswa yang mempunyai kemampuan awal tinggi dan kemampuan awal sedang terhadap hasil belajar matematika pada siswa yang menggunakan strategi pembelajaran MMP. $\mathrm{F}_{11-13}: \mathrm{H}_{0}$ ditolak, maka ada interaksi antara siswa yangmempunyai kemampuan awal tinggi dan kemampuan awal rendah terhadap hasil belajar matematika pada siswa yang menggunakan strategi pembelajaran MMP. $\mathrm{F}_{12-13}: \mathrm{H}_{0}$ ditolak, maka ada interaksi antara siswa yang mempunyai kemampuan awal sedang dan kemampuan awal rendah terhadap hasil belajar matematika pada siswa yang menggunakan strategi pembelajaran MMP. $\mathrm{F}_{21-22:} \mathrm{H}_{0}$ ditolak, maka ada interaksi antara siswa yang mempunyai kemampuan awal tinggi dan kemampuan awal sedang terhadap hasil belajar matematika pada siswa yang menggunakan strategi pembelajaran penemuan terbimbing. $\mathrm{F}_{21-23:} \mathrm{H}_{0}$ ditolak, maka ada interaksi antara siswa yang mempunyai kemampuan awal tinggi dan kemampuan awal rendah terhadap hasil belajar matematika pada siswa yang menggunakan strategi pembelajaran penemuan terbimbing. $\mathrm{F}_{22-23:} \mathrm{H}_{0}$ diterima, maka tidak ada interaksi antara siswa yang mempunyai kemampuan awal sedang dan kemampuan awal rendah terhadap hasil belajar matematika pada siswa yang menggunakan strategi pembelajaran penemuan terbimbing.

Penerapan pembelajaran matematika dengan strategi MMP tidak ada perbedaan yang mendasar dengan pembelajaran yang lazim (konvensional) seperti biasa dilakukan oleh guru-guru selama ini. Bedanya terletak pada penekanannya, dimana pada pembelajaran konvensional lebih menekankan pada deskripsi tujuan yang akan dicapai ( jelas dan operasional) dan tidak ada orientasi siap belajar, sementara pembelajaran dengan strategi MMP lebih menekankan pada skenario pembelajarannya, yaitu kegiatan dengan lima tahapan (dengan memperhatikan kemampuan awal siswa) yang dilakukan oleh guru dan siswa dalam upaya mencapai tujuan pembelajaran yang diharapkan.

Tahap awal pembelajaran MMP yaitu melakukan orientasi sebelum melaksanakan setiap langkah pembelajaran. Pada tahap orientasi, guru mengkondisikan siswa siap belajar. Hal ini dilakukan dengan mendorong siswa untuk: (1) menjadikan belajar sebagai kebutuhan bukan hanya sekedar memenuhi kewajiban, (2) mengubah malas belajar untuk mau belajar, (3) mengubah belajar sebagai sambilan menjadi ada waktu khusus untuk belajar, dan (4) mengubah kemalasan menjadi kesungguhan untuk belajar.

Tahap kegiatan pembelajaran matematika dengan strategi MMP sebagai berikut:

1. Pendahuluan (10'): Apersepsi, orientasi siap belajar, motivasi).

2. Pengembangan ( 20’): pembelajaran konsep/ prinsip secara induktif

3. Penerapan (50"): pelatihan penerapan konsep/prinsip, pengembangan, skill, evaluasi.

a. Latihan Terkontrol: siswa merespon soal, belajar kelompok, dan guru mengamati.

b. Seat work: siswa mengerjakan soal untuk latihan (perluasan konsep). 
4. Penutup (10'): Memberikan Pekerjaan Rumah sebagai latihan, refleksi dan penyusunan rangkuman, dan atau evaluasi.

Sedangkan pembelajaran dengan strategi penemuan terbimbing tahapan kegiatan pembelajarannya sebagai berikut:

1. Pendahuluan (10'): Apersepsi, motivasi dan pembentukan kelompok belajar.

2. Kegiatan Inti (70'):

a. Stimulation ( pemberian rangsangan) : siswa membaca, mempelajari dan mengajukan pertanyaan.

b. Problem statemen (pertanyaan/ identifikasi masalah): siswa mengidentifikasi masalah dan membuat hipotesis.

c. Data collection (pengumpulan data): setiap kelompok melakukan eksperimen dalam rangka pengumpulan informasi.

d. Data processing (pengolahan data): siswa berdiskusi dalam kelompok mengolah hasil yang diperoleh dari eksperimen. untuk menemukan konsep.

e. Verification (pembuktian): siswa berdiskusi dalam kelompok mengerjakan LK untuk menemukan rumus.

\section{f. Generalization kesimpulan): siswa menarik kesimpulan dengan bimbingan guru.}

3. Penutup (10'): refleksi dan penyusunan rangkuman, penugasan dan atau evaluasi.

Hasil belajar matematika pada pokok bahasan transformasi geometri bagi siswa kelas XI SMK Negeri 3 Klaten yang melalui strategi pembelajaran MMP (rerata $=73,6361$ dengan simpangan baku $=7,5161$ ) lebih tinggi dibandingkan hasil belajar matematika yang melalui strategi pembelajaran penemuan terbimbing (rerata $=68,223$ dengan simpangan baku $=6,7650)$. Hasil ini menggambarkan bahwa, siswa kelas
XI SMK Negeri 3 Klaten yang melalui strategi pembelajaran MMP mampu memperoleh hasil belajar lebih baik dibandingkan siswa yang mempelajari melalui strategi pembelajaran penemuan terbimbing. Hal ini didukung oleh hasil penelitian sri lestari (2011) yang menyimpulkan bahwa siswa yang menggunakan model pembelajaran Missouri Mathematics Project menghasilkan prestasi belajar yang lebih baik daripada siswa yang menggunakan model pembelajaran penemuan terbimbing. Sedangkan penelitian Noviyanti (2013) menyimpulkan bahwa melalui pembelajaran Missouri Mathematics Project dapat meningkatkan hasil belajar matematika siswa. Hasil penelitian ini dapat dimaknai bahwa penggunaan strategi pembelajaran Missouri Mathematics Project mampu menghasilkan hasil belajar yang lebih baik.

Hasil belajar matematika pada pokok bahasan transformasi geometri bagi siswa kelas XI SMK Negeri 3 Klaten yang memiliki kemampuan awal tinggi (rerata $=79,742$ dengan simpangan baku = 4,804) lebih tinggi dibandingkan dengan hasil belajar matematika yang memiliki kemampuan awal sedang (rerata $=71,048$ dengan simpangan baku $=5,098)$ maupun siswa yang memiliki kemampuan awal rendah (rerata $=63,557$ dengan simpangan baku = 6,603). Hal ini menggambarkan bahwa siswa yang mempunyai kemampuan awal lebih tinggi mampu memperoleh hasil belajar matematika yang lebih baik Kemampuan awal ini menunjukkan kesiapan siswa dalam menerima pelajaran yang akan disampaikan oleh guru. Menurut pendapat Worrel "kesiapan belajar sebagai suatu yang identik dengan kemampuan dasar yang harus dikuasai dengan prasyarat untuk keberhasilan proses belajar yang akan dimasuki" (Sumantri, 2015: 189). Senada dengan Worrel, Soemanto berpendapat bahwa seseorang baru dapat belajar tentang sesuatu apabila didalam dirinya sudah terdapat kesiapan untuk mempelajari sesuatu (Sumantri, 2015: 189). 
Hasil penelitian ini dimaknai bahwa, dengan kemampuan awal yang tinggi siswa dapat memperoleh hasil belajar yang lebih tinggi.

Hasil penelitian ini menunjukkan strategi pembelajaran MMP dan GD berbeda hasilnya jika dikenakan pada siswa yang mempunyai kemampuan awal sedang, tetapi tidak demikian halnya jika diberikan kepada siswa yang mempunyai kemampuan awal tinggi dan rendah. Hal ini dikarenakan siswa yang mempunyai kemampuan awal sedang setelah diberikan pembelajaran dengan strategi MMP lebih meningkat pemahaman dan kemampuan dalam memecahkan masalah matematika. Keyakinan ini didukung olehpenelitian Febrianti, Caswita dan Yuniarti (2015) bahwa Missouri Mathematics Project berpengaruh terhadap pemahaman konsep matematis siswa dan penelitian Masriah, Sukestiyarno, dan Susilo (2015: 163) menyimpulkan bahwa melalui strategi pembelajaran MMP dapat meningkatkan kemampuan memecahkan masalah materi geometri serta penelitian fauziah, Anna dan Sukasno (2015) menunjukkan model pembelajaran MMP berpengaruh secara signifikan terhadap kemampuan pemecahan masalah matematika. Hasil penelitian ini dapat dimaknai bahwa strategi pembelajaran MMP lebih efektif dibanding dengan strategi pembelajaran penemuan terbimbing apabila diberikan pada siswa yang mempunyai kemampuan awal sedang.

Hasil penelitian ini, juga menunjukkan bahwa pada strategi pembelajaran MMP, siswa yang mempunyai kemampuan awal tinggi hasil belajarnya lebih baik dibanding dengan siswa yang mempunyai kemampuan awal sedang dan rendah, dan siswa yang mempunyai kemampuan awal sedang hasil belajarnya lebih baik dibanding dengan siswa yang mempunyai kemampuan awal rendah. Hal ini di dukung penelitian Faradhila, Sujadi, dan Kuswardi (2013: 67) menunjukkan bahwa model pembelajaran Missouri Mathematics Project menghasilkan hasil belajar matematika yang lebih baik daripada model pembelajaran langsung, baik secara umum maupun ditinjau pada masingmasing tingkat kemampuan spasial siswa. Hasil penelitian ini dapat dimaknai bahwa strategi pembelajaran Missouri Mathematics Project menghasilkan hasil belajar sesuai tingkat kemampuan awal, semakin tinggi kemampuan awal yang dimiliki siswa semakin tinggi pula hasil belajarnya.

Sedangkan pada strategi pembelajaran penemuan terbimbing siswa yang mempunyai kemampuan awal tinggi memperoleh hasil belajar lebih baik dibanding dengan siswa yang mempunyai kemampuan awal sedang dan rendah. Strategi pembelajaran penemuan terbimbing dapat melayani kebutuhan siswa yang memiliki kemampuan diatas rata-rata artinya siswa yang memiliki kemampuan belajar bagus tidak akan terhambat oleh siswa yang lemah dalam belajar (Kurniasih dan Sani, 2015: 114). Kemampuan awal yang dimiliki siswa menjadi pijakan strategi pembelajaran secara optimal karena kemampuan awal demikian penting peranannya dalam meningkatkan kualitas pembelajaran (Sumantri, 2015: 185). Hasil penelitian ini dimaknai bahwa, strategi pembelajaran penemuan terbimbing dapat meningkatkan hasil belajar hanya pada siswa yang mempunyai kemempuan awal tinggi.

\section{Simpulan}

Ada perbedaan pengaruh antara strategi pembelajaran Missouri Mathematics Project dan strategi penemuan terbimbing terhadap hasil belajar matematika dengan taraf signifikansi $\alpha=0,05$. Hasil belajar siswa yang mendapat perlakuan strategi pembelajaran Missouri Mathematics Project lebih baik daripada hasil belajar siswa yang mendapat perlakuan strategi penemuan terbimbing. Dilihat dari rerata marginal ( rerata hasil belajar dengan MMP 73,6361 dan rerata hasil belajar dengan penemuan terbimbing 68,223)

Ada perbedaan pengaruh tingkat kemampuan awal siswa terhadap hasil belajar matematika. Setelah diuji komparasi ganda dengan taraf signifikansi $\quad \alpha=$ 
0,05, diperoleh hasil belajar matematika siswa yang mempunyai kemampuan awal tinggi lebih baik daripada siswa yang mempunyai kemampuan awal sedang dan rendah serta hasil belajar matematika siswa yang mempunyai kemampuan awal sedang lebih baik daripada siswa yang mempunyai kemampuan awal rendah.

Ada interaksiantara strategi pembelajaran dan tingkat kemampuan awal siswa terhadap hasil belajar siswa. Setelah diuji komparasi ganda dengan taraf signifikansi $\alpha=0,05$, diperoleh: a) strategi pembelajaran Missouri Mathematics Project lebih efektif dibanding dengan strategi pembelajaran penemuan terbimbing jika diberikan pada siswa yang mempunyai kemampuan awal sedang; b) pada pembelajaran dengan strategi Missouri Mathematics Project, siswa yang mempunyai kemampuan awal tinggi hasil belajarnya lebih baik daripada siswa yang mempunyai kemampuan awal sedang dan rendah, dan siswa yang mempunyai kemampuan awal sedang hasil belajarnya lebih baik daripada siswa yang mempunyai kemampuan awal rendah; c) pada strategi pembelajaran penemuan terbimbing siswa yang mempunyai kemampuan awal tinggi hasil belajarnya lebih baik dibanding dengan siswa yang mempunyai kemampuan awal sedang dan rendah. Siswa yang mempunyai kemampuan awal sedang dan siswa yang mempunyai kemampuan awal rendah mendapatkan hasil belajar yang sama.

\section{Daftar Pustaka}

Akanmu, M. Alex and Fajemidagba. 2013. Guided-discoveryLearning Strategy and Senior School StudentsPerformance in Mathematics in Ejigbo, Nigeria. Journal of Education and Practice. Vol. 4 (12): 82-89.

Budiyono. 2013. Statistik Dasar Untuk Penelitian. Surakarta : Sebelas Maret University Press 2011. Penilaian Hasil Belajar. Handout Program Pasca Sarjana Universitas Sebelas Maret Surakarta

Coughlan, S. 2015.Asia peringkat tertinggi sekolah global, Indonesia nomor 69 . http://www. bbc.com/indonesia/majalah/2015/05/150513_majalah asia_sekolah terbaik. Diakses Selasa, 1 Maret 2016.

Faradhila, Nora, Imam Sujadi, Yemi Kuswardi. 2013. Eksperimentasi Model Pembelajaran Missouri Mathematics Project (MMP) pada Materi Pokok Luas Permukaan Serta Volume Prisma dan Limas Ditinjau dari Kemampuan Spasial Siswa Kelas VIII Semester Genap SMP Negeri 2 Kartasura Tahun Ajaran 2011/2012. Jurnal Pendidikan Matematika Solusi. Vol. 1 (1): 67-74.

Fauziah, Anna dan Sukasno. 2015. Pengaruh Model Missouri Mathematics Project (MMP) Terhadap Kemampuan Pemahaman Dan Pemecahan Masalah Matematika Siswa SMA N I Lubuklinggau. Jurnal ilmiah Program Studi Matematika STKIP Siliwangi Banding. Vol. 4 (1): 10-21.

Febrianti, Ines, Caswita, Tina Yunarti. 2015. Pengaruh Model Pembelajaran Missouri Mathematics Project terhadap Pemahaman Konsep Matematis Siswa. e-journal.upp. ac.id/index.php/mtkfkip/article/view/265/270. Diakses Selasa, 1 Maret 2016.

Indrianti. 2015. http://www.antaranews.com/berita/496321/mendikbud-rata-rata-nilai-ujiannasional-naik-03-poin. Diakses Senin, 4 April 2016.

Jannah, Miftakhul, Triyanto, dan Henny Ekana. 2013. Penerapan Model Missouri Mathematic Project (MMP) untuk Meningkatkan Pemahaman dan SikapPositif Siswa pada Materi Fungsi. Jurnal Pendidikan Matematika Solusi. Vol.1 (1): 61-66.

Kurniasih, Imas dan Berlin Sani. 2015. Ragam Pengembangan Model Pembelajaran. 
Yogyakarta: Katapena.

Lestari, Sri. 2011. Eksperimentasi Model Pembelajaran Penemuan Terbimbing (Guided Discovery) dan Missouri Mathemetics Project MMP Terhadap Prestasi Belajar Matematika di Tinjau dari Kemampuan Awal Siswa di SMK Kabupaten Klaten. https:// dglib.uns.ac.id/dokumen/abstrak/22283. Diakses Rabu, 11 Mei 2016.

Marliani, Novi. 2015. Peningkatan Kemampuan Berpikir Kreatif Matematis Siswa Melalui Strategi Pembelajaran Missouri Mathematics Project (MMP). Jurnal Formatif. Vol. 5 (1): $14-25$

Masriah, Sukestiyarno, dan Susilo. 2015. Pengembangan karakter mandiri dan Pemecahan Masalah melalui model Pembelajaran MMP pendekatan Atong Materi Geometri. http:// journal unnes.ac.id/sju/index.php/unjme. Diakses Rabu, 11 Mei 2016.

Noviyanti, Hardhina Aprilia. 2013. Peningkatan Kedislipinan Dan Hasil BelajarMatematika Melalui Strategi Missouri MathematicsProject Bagi Siswa Kelas Viii Semester Genap Smp Negeri 1 Cepu Tahun Ajaran2012/2013.http://eprints.ums.ac.id/28131/18/02. Naskah_Publikasi.pdf. Diakses, Rabu 11 Mei 2016.

Sumantri, Mohamad Syarif. 2015. Strategi Pembelajaran: Teoro dan Praktik di Tingkat Pendidikan Dasar. Jakarta: PT Raja Grafindo Persada

Sutama. 2015.Penelitian Tindakan Teori dan Praktek dalam PTK, PTS dan PTBK. Surakarta: Fairuz Media. 